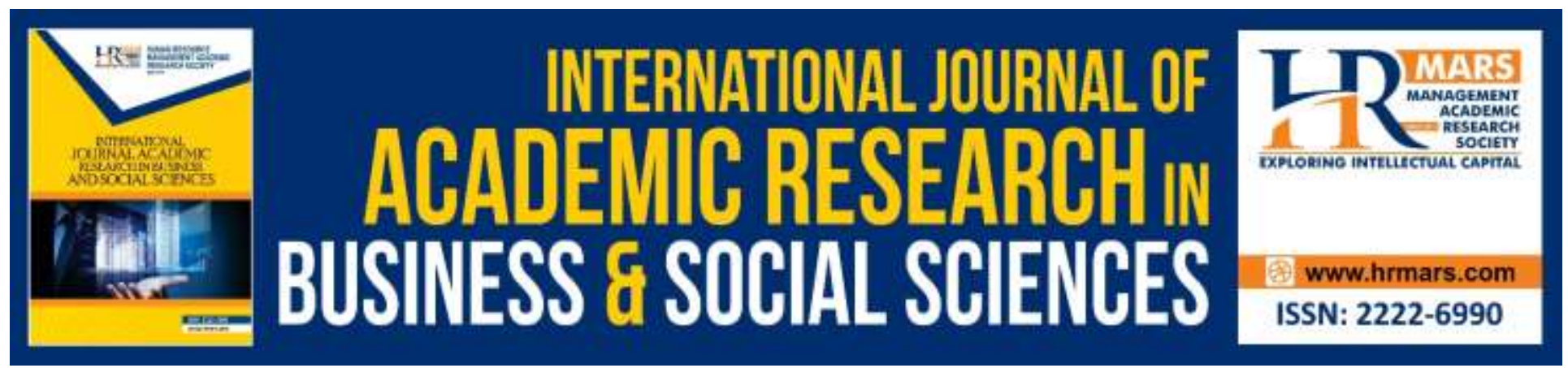

\title{
Management and Distribution of Pusaka Property and Concepts of Munasakhat and Takharuj
}

Nur Syathirah Binti Muhamad Noor, Wan Khairul Aiman Wan Mokhtar, Asma Afifah Rashid

To Link this Article: http://dx.doi.org/10.6007/IJARBSS/v9-i11/6582

DOI: 10.6007/IJARBSS/v9-i11/6582

Received: 12 October 2019, Revised: 30 October 2019, Accepted: 05 November 2019

Published Online: 28 November 2019

In-Text Citation: (Noor, Mokhtar, Rashid, 2019)

To Cite this Article: Noor, N. S. B. M., Mokhtar, W. K. A. W., Rashid, A. A. (2019). Management and Distribution of Pusaka Property and Concepts of Munasakhat and Takharuj. International Journal of Academic Research in Business and Social Sciences, 9(11), 615-622.

Copyright: (C) 2019 The Author(s)

Published by Human Resource Management Academic Research Society (www.hrmars.com)

This article is published under the Creative Commons Attribution (CC BY 4.0) license. Anyone may reproduce, distribute, translate and create derivative works of this article (for both commercial and non-commercial purposes), subject to full attribution to the original publication and authors. The full terms of this license may be seen

at: http://creativecommons.org/licences/by/4.0/legalcode

Vol. 9, No. 11, 2019, Pg. 615 - 622

http://hrmars.com/index.php/pages/detail/IJARBSS

JOURNAL HOMEPAGE

Full Terms \& Conditions of access and use can be found at http://hrmars.com/index.php/pages/detail/publication-ethics 


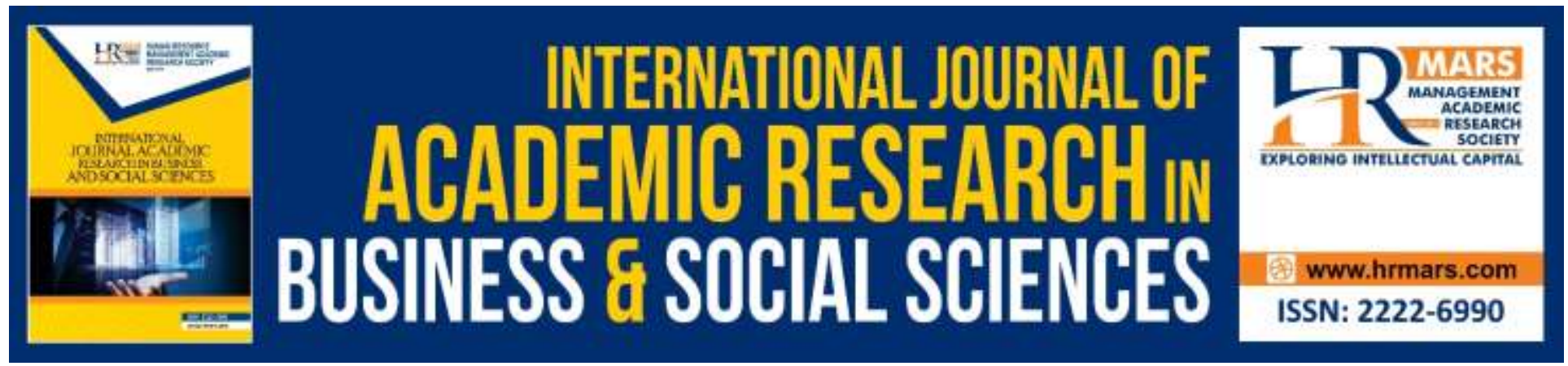

\title{
Management and Distribution of Pusaka Property and Concepts of Munasakhat and Takharuj
}

\author{
Nur Syathirah Binti Muhamad Noor, Wan Khairul Aiman Wan \\ Mokhtar
}

Universiti Sultan Zainal Abidin (UniSZA), Gong Badak Campus, 21300, Kuala Nerus, Terengganu, Malaysia

\begin{abstract}
Asma Afifah Rashid
AAR Tijarah Trading, 3634 Kampung Padang Hiliran, 21000, Kuala Terengganu, Terengganu, Malaysia
\end{abstract}

\begin{abstract}
Management and estate development often become polemic and is an important issue among the people, especially the Muslims. This is because it involves the death and distribution of the estate so that there will be problems especially the fate of each other. Various cases arising from the division of the estate have been featured in newspapers, television and social media. This is evidence that this case is the highest case recorded. Efficient and effective management and allocation of estate through its own institution or heritage is very important. This will not only benefit the society but also to the nation in order to achieve its progress and to develop a fastpaced economy with other developed countries. This article was written to re-define the concepts, goals and benefits when studying Faraid's knowledge. In addition, it also seeks to understand the concept of problems that often occur in the process of management and distribution of the estate, namely Munasakhat which means layered death and also Takharuj the heir who withdraws from receiving the inheritance that is entitled to it. To facilitate this study, qualitative research has been used. In addition, this study also uses more research and descriptive methods. The collection of data used is through the collection of information from the library. Finally, data is analyzed using content analysis. The findings show that the issues highlighted in this discussion are often the reason for deferring the process of management and allocation of the estate. Understanding the concepts, goals and benefits of learning it will hopefully be the guide to the community in resolving the cases of inheritance so there is no longer a postponement of the estate.
\end{abstract}

Keywords: Faraid, Shariah, Consepts, Management and Distribution, Munasakhat and Takharuj 


\section{Introduction}

Management and distribution of Islamic conceptual estate focuses more on issues of settlement of property, the will of the deceased and this shows that Faraid's knowledge is very important to learn. However, this knowledge is not taken care of by the community and is not applied to the academic measure either in low or high education. In essence, it should be compulsory for all individuals to learn as a foundation in a balanced property management as defined by the Shariah. If the Muslims do not pay attention to the management and distribution of the estate then there is an undesirable and prolonged issue and is a problem for the community, especially those who are Muslims (Zaidi, 2015).

As is well known, faraid knowledge or better known as knowledge management and distribution of inheritance is one of the fundamental or fundamental sources of knowledge in Islam where the Messenger of Allah S.A. puts this knowledge at a very high level compared to the other sciences of Allah. Rasulullah SAW said that narrated from 'Abdullah bin 'Amr bin al-'As which means: "the knowledge is three and apart from the three it is merely a surplus, ie the sentence of the law (the undated law), the authentic sunnah narrated from Rasulullah SAW and the knowledge to divide a fair estate." (history of Abu Daud and Judge)

But as it happens in this new millennium, faraid-related knowledge is ignored by society. This can be proved when it is very difficult to find a faraid group that is faraid and even the knowledge is less shared in science occasions. It is not surprising if the Prophet S.A.W once said that this knowledge is the earliest knowledge will be deprived of his people. As a result, various troubles and problems arise in matters involving this estate.

This journal article is published to disseminate the knowledge gained in the discussion on the management and distribution of the estate. In addition, it also seeks to identify problems that often arise when faced with the process of managing and distributing the estate. Hence the journal article has been using the library service to obtain relevant information sources.

Generally, this journal article will discuss two related issues namely the first on general management and allocation of the estate while the second on the concept of Munasakhat and Takharuj.

\section{Research Methodology}

To produce a study, research methodology has been required. Research methodology is important to make a study organized and comprehensive. To facilitate this study, qualitative research has been used (Mokhtar, 2017; Piragasam \& Unoon).

This study uses library research. This study using observational methods for descriptive methods. The collection of data used is through the collection of information from the library. Finally, data is analyzed using content analysis. From the analysed data, the conclusion was made. (Wan Mokhtar, 2017). 


\section{Findings and Research Discussion}

To discuss more about the management and distribution of the estate then it is divided into three categories. The first, the introduction to faraid knowledge. The second, the concept of Munasakhat and the last of Takharuj.

\section{Introduction to Faraid Knowledge}

The general knows that faraid comes from the Arabic word plural to Faridhah derived from his original word Fard which means al-Taqdir meaning "destined". Hence, it can be concluded here the real definition of faraid knowledge is the knowledge of the division of the estate or also known as the inheritance or the knowledge of al-takah which is the knowledge related to the property of the deceased (Harun, 2013; Apriani, Heryanto 2018).

Faraid knowledge has two different definitions:

1. Faraid knowledge is the fiqh of the heredity and the knowledge of the Hezbollah that it is permissible to convey to know what is forbidden to those who have the right to the property of the deceased.

2. Knowledge of faraid is also known as the fiqah and reckoning method whereby by this method the right of every person heirs to the property of the deceased is known.

From the definition described, we can conclude that faraid knowledge is formed through a combination of two knowledge namely Fiqah and Mathematics. Although the knowledge of Fiqah is more emphasized in the two sciences namely Nasab knowledge and the knowledge of Fatwa. In conclusion, the combination of the three sciences namely nasab knowledge, fatwa knowledge and mathematical science led to the formation of Faraid's knowledge (Bahari, 2012).

However, to learn and explore faraid knowledge must be included. For example:

1. As a base to know whether the property is an estate or otherwise. this is because most of the people are mistaken among hibah and will. The estate cannot be pre-approved prior to the granting of a grant and a will.

2. As a means of knowing the heirs who are entitled to the property of the deceased. this matter is focused on Nasab's knowledge of the reasons and conditions for inheritance of property, fallen clause or barrier from inheritance to inheritance.

3. As one way to know which part of the inheritance is entitled to each heir because Faraid has its own calculation method. The division method is divided into two ie fardu and asabah which involve problems such as aul, musytarikah, muqasamah and so forth.

Islam encourages its followers to study Faraid's knowledge more profoundly because it is one of the branches of fiqh science that is given the highest rank by Islam. Various problems can arise if Faraid's knowledge is not studied as an example of inheritance division does not use the proper method. Will likely also result in a split between a family that leads to misunderstanding, hostile or heavier criminal cases (Sabirin, 2008; Griva, Dinas, \& Flegas, 2018).

\section{Concept of Munasakhat}

Like Faraid also, Munasakhat is also derived from the Arabic word which means to move, delete and cancel. The actual word for Munasakhat is Munaskhah and comes from Nasakha. Based on 
the term Faraid science, Munasakhat can be explained by situations such as some of the beneficiaries who have the right to the property of the deceased have died before the property is divided on him and faraid the property which he ought to belong to has to be given to another person or heir. This can be explained through situations such as a dead leaving his wife, mother, father, 3 sons and 2 daughters. However the deceased's mother was confirmed dead before the estate was divided according to their respective rights. This is what causes the property to move to another heir (Awang, 1998). There are two important components in the case of death: the time and date of death. This problem will not exist if it is certain to die together. For example, in a road accident, it is unknown whether any of the deceased's family members died. Therefore, it does not mean that each has no right to inherit the estate.

This applies if there is a situation involving unintended death. it means there are simultaneous deaths and some die a few minutes, hours, weeks or years afterwards. For example, a road accident involving a child and father lives. The father reportedly died first while his son died a day after the accident (Harun, 2013). Therefore, Munasakhat exists where the estate of the father will be distorted to the heirs including the deceased child later. However, the property entitled to the deceased child will be divided into other beneficiaries using the simultaneous calculation of Munasakhat's calculation method.

The causes of Munasakhat are often associated with layered deaths that occur due to two conditions. The first condition of destiny while the second is deliberate as a result of the distraction of inheritance.

1. Had been fated

Delayed layered deaths usually involve disaster or epidemic. For example natural disasters involving tsunamis, earthquakes, landslides, floods and droughts. Besides, road accidents or fires. Women who die maternity and are followed by the baby are also categorized as layered deaths. In short, mortal death is a death involving family members and the death occurs one by one.

2. Intentional consequence of the preference of preaching of inheritance

The disengagement attitude of this heirloom is one of the causes that led to the existence of Munasakhat especially in urban areas or in circumstances where only property was left by the deceased. This can be proved that there are still many land still registered with the name of the deceased. This explains that the heirs still have not solved the problem of inheritance. This results in a case as there are 50 deaths who sometimes die more than that due to the layered mortality.

\section{Concept of Takharuj}

The word Takharuj is taken from the Arabic word Kharaja which means exit. Based on the term Faraid knowledge, Takharuj means withdrawal from accepting the share of the estate either partially or wholly by giving its share to a person or several persons or all other heirs. The distribution is made voluntarily or is promised grounds or remuneration or payment of damages made from the heirs or in any other manner which is to surrender part of the estate to him (Kadir, 2002). 
The purpose of reward, remuneration or damages is the amount of fixed assets granted to the heirs who withdraw after the consent of both parties between the withdrawal of beneficiary and the beneficiary who will receive the share of the withdrawal. The reward can be taken from the inheritance property which receives rejection or is taken part of the estate according to the consent of the parties involved in the Takharuj process.

If the withdrawal heir reaches agreement with a person or some person or any of the beneficiaries involved in receiving a certain payment from the heirs where it is derived from the inheritance property which agrees to represent the withdrawal of the heir apparently sells its share to the other heirs. However, if the withdrawal of the heirs surrendered his share to the other heirs voluntarily then that means his share to the other heirs is considered a grant (Latif, 2012).

The consent to which the heirs of the withdrawal to take part of the estate shall not be in the case of one person to one or more persons but shall be between one and the other beneficiaries entitled to the estate of the deceased. This is because the estate is also the right of other heirs, so the other heirs are entitled to benefit from it.

In general, Takharuj took place in the time of al-Rashidin involving Abdul Rahman Auf and his wife. Abdul Rahman Auf divorced his wife Tumadhir bint al-Asbagh when he was ill when the illness led to death. Shortly afterwards, Abdul Rahman Auf was confirmed dead when Tumadhir was still in an idol. Through the help of Saidina Umar r.a, he has distributed the inheritance to Tumadhir along with the other three wives of Abdul Rahman Auf. While still in the division period, the heirs agreed to replace 1/4 from 1/8 of Tumadhir's share to 93000 dinars or dirhams (AlZuhayli, 2003).

\section{Form of Takharuj}

Agreed to say Takharuj can be categorized into three forms which is:

1. Withdraw by accepting retaliation taken from inheritance.

2. Wthdraw yourself by receiving a reply from the estate itself.

3. Voluntarily withdraw without expecting a reply.

This withdrawal may occur between one or more persons expressing consent that comprises:

1. A heir

2. Some of the heirs

3. All other heirs

The consent made involves several heirs or all heirs explaining that eligible beneficiaries of the withdrawal portion of the inheritance may divide the property in such manner (Wan Abdul Halim, 2013):

1. The part of the heirs who withdraws are divided equally

2. The withdrawal portion of the heirs is divided according to the amount paid to the withdrawal of the heirs.

3. The withdrawal portion of the heirs is divided according to the Faraid method. 


\section{Conclusion}

Faraid's knowledge is very important and is encouraged to learn it. This is because with this knowledge the problem of making the distribution of the estate can be solved even the division can be completed based on the rules set. Therefore, it should be emphasized here that the right of the deceased should be completed first before the distribution process takes place. For example, the management of the funeral, funeral of the deceased, settling the debt of the deceased and fulfilling the will of the deceased. Once completed, the balance of the property can be divided according to Faraid's method to those who are entitled to receive certain conditions and that there must be no obstacle which may result in failure to receive inheritance. Similarly, the concept of Munasakhat in which it arises when a situati like a heir entitled to receive the estate dies before the estate of the deceased was first divided and his share was distributed to the other heirs. Nevertheless, in the case of Takharuj, he explained that the heirs with the right to receive the share still alive but withdraw from the inheritance and his share was given to other heirs.

\section{Acknowledgement}

This paper is founded on the research project of the Fundamental Research Grant Scheme FRGS/1/2018/SSI03/UNISZA/02/2 (Project No: RR279). Special appreciation is owed to Ministry of Higher Education Malaysia (MOHE) and Universiti Sultan Zainal Abidin (UniSZA) for sponsoring and supporting this research.

\section{Corresponding Author}

Wan Khairul Aiman bin Wan Mokhtar (Ph.D), Senior Lecturer, Universiti Sultan Zainal Abidin (UniSZA), Gong Badak Campus, 21300 Kuala Nerus.

E-mail: wk_aiman@yahoo.com / wkhairulaiman@unisza.edu.my

\section{References}

Al-Zuhayli, W. (2003). Al-Figh al-Islami wa Adillatuh. Juzuk 8. Beriut: Dar al-Fikr.

Apriani, Y., Heryanto (2018). The Effect of Organizational Culture and Compensation on EmployeePerformance with Satisfaction as Intervening Variables in the Sub District Office of South Sipora Mentawai Islands Regency, International Journal of Academic Research in Accounting, Finance and Management Sciences 8 (4): 101-109.

Awang, M. R. (1998). Undang-undang dan Pentadbiran Harta Pusaka Orang Islam di Malaysia. Selangor: Polygraphic Sdn. Bhd.

Bahari, A. (2012). Soal Jawab Wasiat Islam. Perpustakaan Negara Malaysia. Telaga Biru Sdn. Bhd.

Griva, E., Dinas, K. \& Flegas, K. (2018). Language Program «Modern Greek Paideia»: A record of educational needs in the 'Aristotelis' school of Toronto. Multilingual Academic Journal of Education and Social Sciences, 6(1), 113-125 (in Greek).

Harun, W. A. H. (2013). Pengurusan dan Pembahagian Harta Pusaka. Perpustakaan Negara Malaysia. Utusan Printcorp Sdn. Bhd. 
Ismail, A. K. (2002). Sistem Pusaka Islam. Kuala Lumpur: Yayasan Dakwah Islamiah, Cetakan Pertama.

Latif, A. R. (2012). Hukum Pusaka dalam Islam, Satu Kajian Perbandingan. Cetakan Pertama, Academy Art \& Printing Services Sdn. Bhd.

Mokhtar, W. K. A. W. (2017). Concept Al-Hadīth Al-Mawḍu'iy as a Method of Collecting and Analyzing Research's Data. International Journal of Academic Research in Business and Social Sciences, 7(2), 2222-6990.

Piragasam, G. A., \& Unoon, A. R. I. (2018). Attention Span Remediation of Attention Deficit Hyperactive Disorders (ADHD) Preschoolers with Music as Learning Background. International Journal of Academic Research in Progressive Education and Development, 7(4), 148-157.

Sabirin, A. (2008). Pengurusan Harta Pusaka. Majalah Usahawan Sukses. 